\title{
PERUBAHAN DAN KERENTANAN PENGHIDUPAN RUMAH TANGGA NELAYAN BERBASIS PERIKANAN TERUBUK DI KABUPATEN BENGKALIS PROVINSI RIAU
}

\section{CHANGE AND VULNERABILITY OF FISHERY-BASED FISHERY HOUSING LIABILITY IN BENGKALIS DISTRICT PROVINCE RIAU}

\author{
Afrizal, ${ }^{1}$ Zulkarnaini, ${ }^{1}$ Victor Amrifo, ${ }^{1}$ \\ 1 Kekhususan Agribisnis Perikanan Magister Ilmu Kelautan, Fakultas Perikanan dan Kelautan, \\ Universitas Riau, Jl. HR Soebrantas Km 12,5 Simpang Baru, Panam-Pekanbaru Indonsia 28293 \\ Correspondence Author: naini61gope@gmail.com
}

\section{A R T I C L E I N F O}

Submitted: 29 April 2018

Revised : 12 Mei 2018

Approved: 02 Juni 2018

\begin{abstract}
Abstrak
The objective of this research is to collect fishery based household livelihood vulnerability database, to know government efforts in reducing the vulnerability and to maintain the sustainability of fisherman's livelihoods based on terubuk. The research method is conducted qualitatively by involving informants directly or indirectly with fishing activities and fishery business terubuk. The results showed that the change of livelihood of fisherman fishery-based fishermen was caused by environmental change either from ecological asphek or from social culture asfek. Being a fisherman is a derivative work of the ancestors, the sources of vulnerability that occurs not only from natural capital (fish terubuk) but also socially, economically, and politically, the vulnerabilities of fisherybased fishery-based households are initially shaky. This vulnerability is a seasonal trend and is a habit for fishermen.
\end{abstract}

\begin{abstract}
Abstrak
Penelitian ini bertujuan mengumpulkan basis data kerentanan penghidupan rumah tangga nelayan berbasis perikanan terubuk, mengetahui upaya-upaya pemerintahdalam mengurangi kerentanan dan menjaga keberlanjutan penghidupan nelayan berbasis perikanan terubuk. Metode penelitian dilakukan secara kualitatif dengan melibatkan informan secara langsung maupun tidak langsung dengan aktivitas penangkapan maupun usaha perikanan terubuk. Hasil penelitian menunjukkan perubahan penghidupan rumah tangga nelayan berbasis perikanan terubuk disebabkan terjadinya perubahan lingkungan baik itu dari asfek ekologikal maupun dari asfek sosialkultur, Menjadi nelayan terubuk merupakan pekerjaan turunan dari nenek moyang, sumber-sumber kerentanan yang terjadi bukan saja dari natural kapital (ikan terubuk) nya saja, tetapi juga dari sisi sosial, ekonomi, maupun politik, kerentanan-kerentanan yang terjadi pada rumah tangga nelayan berbasis perikanan terubuk ini awalnya bersifat goncangan lama-kelamaan kerentanan ini bersifat tren musiman dan menjadi kebiasaan bagi nelayan.
\end{abstract}

Kata kunci:

Perubahan, Kerentanan penghidupan rumah tangga, perikanan terubuk 


\section{PENDAHULUAN}

Perubahan penghidupan rumah tangga masyarakat nelayan terubuk yang sudah berubah penghidupannya pada aktivitas sebagai nelayan tradisional yang memanfaatkan sumbersumber penghidupan di perairan Laut Bengkalis, dengan teknologi yang disesuaikan.Perubahan penghidupan ini tentunya dipengaruhi oleh banyak faktor. Menurut Chambers dan Conway (1992), dan Koeberlien (2003), asset penghidupan (livelihood asset) adalah merupakan faktor-faktor internal penghidupan yang terdiri dari 5 asset capital, yakni: asset modal sumberdaya manusia, asset modal sumberdaya alam, asset modal sumberdaya fisik asset modal sumberdaya finansial, dan asset modal sosial. Asset sumberdaya manusia adalah jumlah dan kualitas tenaga kerja yang tersedia pada rumah tangga, Asset sumberdaya alam adalah meliputi sumberdaya alam yang dikuasai atau dimiliki oleh rumah tangga berkaitan dengan penghidupannya,Asset fisik terdiri dari infrastrukturdan alat-alat produksi yang dapat diakses atau dimiliki oleh rumah tangga, Asset finansial adalah sumberdaya finansial yang diperlukan untuk mengsupport penghidupan rumah tangga, dan asset modal sosial (social capital) meliputi keterlibatan rumah tangga dalam aktivitas sosial dan ekonomi. Faktor eksternal livelihood adalah berkaitan dengan kerentanan dan tranformasi struktur dan proses. Kerentanan meliputi: risiko, tekanan, keadaan darurat dan ketidaktentuan pada mana suatu rumah tangga dapat diarahkan. Akses pada asset dan skop dari aplikasi dipengaruhi oleh konteks srtruktural yang meliputi: hukum, kebijakan, kelembagaan, dan penguasaan. Konteks struktural juga memiliki dampak pada strategi livelihood.

Menurut Chambers dan Conway (1992), dan Koeberlien (2003), asset penghidupan (livelihood asset) adalah merupakan faktor-faktor internal penghidupan yang terdiri dari 5 asset capital, yakni: asset modal sumberdaya manusia, asset modal sumberdaya alam, asset modal sumberdaya fisik asset modal sumberdaya finansial, dan asset modal sosial.

$\begin{array}{ccl}\text { Salah } & \text { Satu dampak dari } \\ \text { perubahan } & \text { sosial dan budaya }\end{array}$ masyarakat adat yang menjadi focus perhatian saat ini adalah perubahan penghidupan (Livelihood change), pentingnya studi perubahan penghidupan sesunggungnya telah lama disadari oleh sosiologi pedesaan yang menekuninnya. Sejauh ini sumberdaya alam yang dikelola oleh masyarakat nelayan adalah dengan memanfaatkan ikan terubuk dengan sistem teknologi tradisional, ikan terubuk merupakan salah satu jenis ikan yang mempunyai nilai ekonomi yang tinggi dan pengelolaan dilakukan oleh masyarakat dari komunitas local.

Untuk ikan terubuk yang ada di Bengkalis ini, terkait dengan faktor pertama dan kedua yaitu kelebihan penangkapan dan pencemaran. Upaya yang dapat dilakukan untuk pencegahan dan pelestarian ikan terubuk ini yaitu, dengan cara mengatur penangkapan ikan, membuat kawasan perlindungan, dan membuat penangkaran untuk budidaya ikan terubuk tersebut. Pencemaran laut merupakan masuknya zat, energi, makhluk hidup atau komponen lain yang diakibatkan oleh kegiatan manusia yang menyebabkan penurunan kwalitas dari suatu perairan laut. Adapun yang menyebabkan pencemaran laut diantaranya yaitu sampah, limbah, dan aktivitas kapal yang melintasi perairan laut tersebut. Informasi penting tentang ikan terubuk telah ditemukan seperti data tentang kebiasaan makan, biologi reproduksi, pola migrasi, daerah pemijahan, dan sosial ekonomi dari nelayan terubuk. Namun, keadaan kondisi populasi dan tingkat eksploitasi dari ikan terubuk itu 
sendiri pada saat ini belum ada dilakukan.

Tujuan dari penelitian ini adalah Untuk mengidentifikasi dan menganalisis faktor-faktor Penyebab perubahan dan kerentanan penghidupan rumah tangga nelayan berbasis perikanan terubuk, Untuk menganalisis Konteks kerentanan social ekologi nelayan berbasis perikanan terubuk, untuk menganalis dan mengetahui upaya-upaya pemerintah dalam mengurangi kerentanan dan menjaga keberlanjutan penghidupan nelayan berbasis perikanan terubuk

\section{METODE PENELITIAN \\ Waktu dan Tempat}

Penelitian ini dilaksanakan pada Januari-Februari 2018, Penelitian ini dilaksanakan di desa-desa tempat bermukimnya komunitas masyarakat nelayan berbasis perikanan terubuk yang berada di Kabupaten Bengkalis,Provinsi Riau.

Penelitian ini tergolong dalam penelitian kualitatif, karena penelitian ini mempelajari benda-benda dalam konteks alaminya, serta berupaya untuk memahami dan menafsirkan fenomena yang melekat pada benda tersebut, melalui metoda yang tepat. Penelitian ini menekankan pada proses, pemaknaan subjektif atas realitas yang terbangun secara social, dan tidak bebas nilai.

\section{Penentuan Responden}

Sumber informasi/ informan dalam penelitian ini terdiri dari orangorang yang terlibat langsung maupun tidak langsung dengan aktivitas penangkapan maupun usaha perikanan terubuk . Tokoh-tokoh masyarakat, Ketua Kelompok, Ketua Lembaga, Nelayan yang disegani atau nelayan senior, Orang yang dituakan/sesepu adat, Kepala Desa, Masyarakat Nelayan

\section{Pengumpulan Data}

Data yang dikumpulkan dalam penelitian ini adalah data primer dan data sekunder. Data primer dikumpulkan dari informan yang menjadi responden dan pihak-pihak yang terkait .Data primer dikumpulkan melalui wawancara mendalam (indeef interview) dengan berpandukan pada kuiesioner yang telah disiapkan.Sedangkan data sekunder dikumpulkan dari instansi-instansi pemerintah dan bahan publikasi yang dikumpulkan dengan metode studi dokumen. Pada penelitian ini digunakan teknik penelitian lapangan yaitu wawancara Mendalam, Diskusi Kelompok, Observasi, Dokumentasi.

\section{Interpertasi Data}

Interpertasi adalah hal terpenting di dalam penelitian yang bekerja mengikuti paradigma konstruksivisme. Interpertasi merupakan konstruksi terhadap pembacaan peristiwa-peristiwa dilapangan penelitian menuju ke teks (narasi), melalui dialektika antara peneliti dan teliti dan antara paradigma /teori dengan fakta yang ditemukan dilapangan, data yang telah dapat diakui keabsahannya di interpertasikan sesuai dengan tujuan penelitian.

Analisis data adalah proses penyempurnaan data dalam bentuk yang lebih mudah dibaca dan diinterprestasikan. Data yang diperoleh ditabulasikan dan kemudian dianalisis secara Kualitatif dan Kuantitatif dengan menggunakan Subsinebel Livelihood

\section{HASIL DAN PEMBAHASAN \\ Perubahan Penghidupan Rumah Tangga Nelayan Berbasis Perikanan Terubuk.}

Sistem nafkah dan sistem penghidupan nelayan terubuk merupakan kumpulan dari keseluruhan cara, taktik, mekanisme, serta manipulasi yang dibangun oleh individu, atau kelompok rumah tangga masyarakat dalam upaya 
mempertahankan dan menjaga keberlanjutan kehidupan. Perairan Selat Bengkalis yang merupakan fishing ground ikan terubuk dari dahulu sampai sekarang, yang mana sekarang kondisi perairan selat bengkalis sudah banyak mengalami perubahan seperti tercemarnya perairan yang disebabkan oleh limbah minyak, limbah rumah tangga, dan sampah-sampah serta di pengaruhi oleh transportasi laut yang membuat jaring nelayan sobek, dengan kondisi demikian membuat nelayan berpindah mata pencarian, bekerja sebagai nelayan terubuk dianggap sebagai pekerjaan sampingan saja, yang merupakan suatu strategi penghidupan. Natural capital dan fisikal capital, menjadi pilihan dan kombinasi baru untuk mempertahankan kehidupan dan penghidupan mereka.Human capital yang dibutuhkan tidak lagi sekedar kekuatan fisik, serta keahlian dan pengetahuan untuk bertahan hidup.Masyarakat nelayan terubuk juga membutuhkan pengetahuan tentang bagaimana memasarkan barang dan jasa guna mempertahankan sistem penghidupan yang baru.

Dahulu masyarakat nelayan terubuk memanfaatkan perairan selat bengkalis untuk melakukan usaha penangkapan bermacam jenis ikan terkhususnya ikan terubuk, yang mana jenis ikan terubuk diperairan selat bengkalis sangat banyak dan mudah dijumpai dalam jumlah yang banyak, dalam menjalankan usaha penangkapan ikan terubuk ini masyarakat nelayan bengkalis masih bersifat kecil dan sederhana ini bisa terlihat dari jenis armada dan alat tangkap yang digunakan masih secara tradisional begitu juga jarak daerah penangkapan tidak jauh dari pemukiman masyarakat tetapi hasil tangkapannya nelayan banyak dan melimpah bahkan bisa membuat perahu nelayan bisa tenggelam, usaha penangkapan diperairan bengkalis dilakukan nelayan hampir setiap hari, yang mana dahulu kondisi perairan selat bengkalis masih bagus dan tidak tercemar boleh dikatakan waktu itu tidak ada kendala bagi nelayan dalam menjalankan usaha penangkap dan mengoperasi alat tangkapPerubahan penghidupan ini tentunya dipengaruhi oleh banyak faktor. Menurut Chambers dan Conway (1992), dan Koeberlien (2003), asset penghidupan (livelihood asset) adalah merupakan faktor-faktor internal penghidupan yang terdiri dari 5 asset capital, yakni: asset modal sumberdaya manusia, asset modal sumberdaya alam, asset modal sumberdaya fisik asset modal sumberdaya finansial, dan asset modal sosial. Asset sumberdaya manusia adalah jumlah dan kualitas tenaga kerja yang tersedia pada rumah tangga.

\section{Sejarah Terubuk}

Sejarah terubuk merupakan salah-satu tradisi atau budaya lama yang sering dipringati dan dijalankan oleh Raja bersamaan diperairan Selat Bengkalis khususnya di Tanjung Jati, dahulunya zaman terubuk ini dilaksanakan untuk melestarikan dan menjaga ikan terubuk supaya ikan terubuk tetap banyak dan lestari, konon katanya ikan terubuk ini membuat nelayan tidak berani melakukan usaha penangkapan ikan terubuk selama proses terubuk berjalan. Nelayan tidak akan menangkap 7 hari sebelum dan 7 hari sesudah sesudah pelaksaan semak terubuk, selama semak terubuk ini berjalan bagi nelayan yng menagkap pada waktu itu akan menjadi orang gila seperti dapat membuat nelayan menjadi lebih takut dan ini benar-benar terjadi. Selama Semak terubuk dijalankan jumlah ikan terubuk memang banyak dan dan hampir dikuasai oleh Raja-raja laksamana. Dengan kemajuan zaman yang modern dari tahun-ketahun, tradisi ini sudah mulai berkurang dan bahkan sudah hilang ditelan waktu semak terubuk ini sudah tidak dijalankan atau diperingati lagi sekarang. Hal ini 
dipengaruhi oleh mahal dan memerlukan biaya yang besar. Selain itu orang yang untuk menjadikan pewarisan semak terubuk ini juga tidak ada karena haruslah orang yang mempunyai garis keturunan Raja Laksamanan. Dan sekarang ada yang mempunyai garis keturunan raja laksamana tetapi sudah tua dan pikun ninilah yang membuat samapai sekarang Semak terubuk tdak di laksanakan lagi.

\section{Perubahan Iklim}

Perubahan iklim merupakan perubahan yang terjadi secara signifikan mengenai pola cuaca yang dihitung berdasarkan angka statistik dalam rentang waktu puluhan hingga ratusan tahun lamanya. Banyak faktor yang mempengaruhi perubahan iklim seperti proses biologis, radiasi sinar matahari, tekanan teknonik, erupsi gunung berapi, tingkah laku manusia sperti aktivitas manusia melakukan penebangan hutan secara liar, terjadinya fenomena pemanasan global, terjadiny EL Nino dan EI Nina dilautan, menipisnya lapisan ozon di atmosfer bumi (Enviromental Protection, 2014).

Perubahan iklim yang terjadi diBengkalis menyebabkan kecendrungan perubahan cuaca, perubahan iklim ini sulit untuk di prediksi dan berdampak langsung terhadap pendapatan nelayan khususnya dan umunya hampir semua pekerjaan sperti perubahan iklim berdampak pada musim angin yang cepat berubah dan sulit ditentukan akibat pola cuaca yang tidak beraturan dan perubahan iklim ini juga ditentukan akibat pola cuaca yang tidak beraturan dan perubahan iklim ini menentukan mata pencaharian yang ada.

\section{Sruktur Nafkah Rumah Tangga Nelayan}

Struktur pendapatan rumah tangga dapat dilihat dari sumbangan setiap bentuk aktivitas nafkah terhadap total pendapatan rumah tangga. Komposisi nafkah rumah tangga nelayan terubuk yang diwakil oleh 52 rumah tangga yang dikaji menunjukkan bahwa kegiatan nafkah utama dan nafkah sampingan dari rumah tangga nelayan terubuk berbasis perairan. Semua $(100 \%)$ rumah tangga $(n=34)$ di lokasi studi (Penampi $\mathrm{n}=18$, sungai alam $n=3$, dompas $n=6$, dan sejanggat $\mathrm{n}=7$ ), sebagian besar menjalankan aktivitas nafkah utama dan sampingan yang berbasis perairan (gambar 1.)

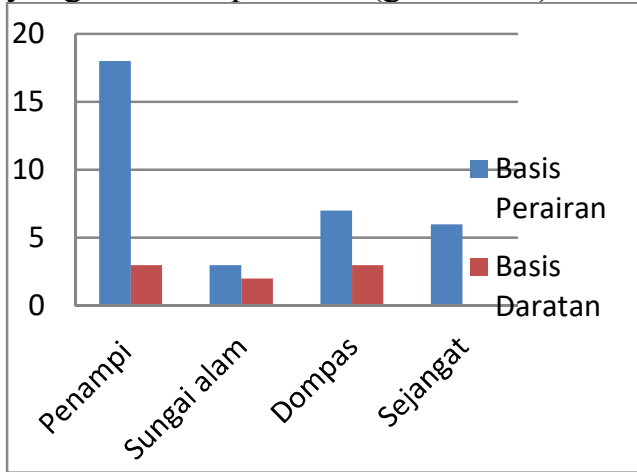

Gambar 1. aktivitas nafkah Rumah Tangga nelayan Berbasis Perikanan Terubuk

\section{Perubahan Kombinasi Sumberdaya Nafkah}

Sistem nafkah atau sistem penghidupan (livelihood system) nelayan Terubuk merupakan kumpulan dari keseluruhan cara, taktik, mekanisme, serta manipulasi yang dibangun oleh nelayan terubuk pada berbagai cara dalam upaya mempertahankan dan menjaga keberlanjutan kehidupan, serta meningkatkan derajat sosio-ekonomi. Basis nafkah yang pada awalnya hanya mengandalkan sumberdaya nafkah di lautan, berkembang menjadi kompleks. Natural kapital dan fisikal kapital yang ada di lautan menjadi pilihan dan kombinasi baru untuk mempertahankan kehidupan dan penghidupan mereka.

Kapital manusia yang dibutuhkan tidak lagi hanya sekedar kekuatan fisik, serta keahlian dan pengetahuan untuk bertahan dalam 
kerasnya lingkungan biofisik lautan, Nelayan terubuk membutuhkan pula keahlian dan pengetahuan tentang bagaimana memasarkan barang dan jasa. Keahlian-keahlian lain seperti bertukang, pengolah hasil perikanan. Guna mempertahankan keberlanjutan sistem penghidupan di lingkungan yang baru, nelayan terubuk juga harus mempertimbangkan aspek sosial kapital dan finansial capital.

Natural kapital yang berkaitan dengan penghidupan nelayan terubuk sumberdaya perairan selat bengkalis adalah sumberdaya perikanan laut. Sumberdaya perikanan yang didapatkan diperairan laut beraneka jenis ikan seperti ikan juaro, ikan lomek, ikan terubuk, dll. Sumberdaya nafkah yang berkaitan dengan natural capital adalah fisikal capital. Kondisi fisikal kapital bagi masyarakat yang tinggal di Bengkalis pada tahun 2006 kondisi perairan sangat mendukung bagi keberlangsungan hidup natural capital yang mereka manfaatkan. Pada tahun 2017 ini perairan sudah tercemar, sehingga hasil tangkapan nelayan berkurang. Hal ini berasal dari aktivitas manusia maupun yang berlangsung secara alami terus dirasakan sampai saatini. Modal fisika yang juga berkaitan dengan proses produksi adalah armada dan alat penangkapan ikan. Rumah tangga nelayan dalam hal ini nelayan tangkap menggunakan alat tangkap berupa kapal yang sederhana yang bermuatan 2-4 orang. Sedangkn alat tangkap yang digunakan adalah jaring gillnet. Dampak tercemarnya perairan tersebut natural capital dimanfaatkan seperti transfortasi kapal yang tempat lalu lintas membawa minyak, tempat berlabuhnya kapal yang dari luar. Modal fisikal yang lainnya seperti armada penangkapan untuk menangkap ikan dapat dimanfatkan transportasi penyeberangan. Selain peairan rumah tangga nelayan juga memanfaatkan rawa gambut yang berkaitan dengan aktivitas perkebunan kelapa dan kelapa sawit. Modal sosial yang dibangun dan dikembangkan oleh rumah tangga nelayan adalah saling memberi antara anggota komunitas batin, tolong-menolong dan saling berbagi, serta memperkuat hubungan antar sesama kerabat, pinjam meminjam, serta kesadaran menjaga perairan.

\section{Faktor-faktor yang Mempengaruhi Perubahan Penghidupan RumahTangga Berbasis Perikanan Terubuk \\ Faktor Internal \\ Usia}

Nelayan yang berubah penghidupannya yang dijadikan Informan pada penelitian ini berjumlah 34 rumah tangga, dimana dari jumlah tersebut sebagian besar nelayan berada pada kelompok umur sangat produktif. Hal ini didukung oleh pendapat Kamaludin (1994), bahwa umur akan mempengaruhi seseorang dalam mempelajari,memahami dan menerima suatu pembaharuan. Selain itu umur juga mempengaruhi produktivitas kerja seseorang.

Tabel 1. Sebaran Informan Nelayan berbasis perikanan Terubuk Berdasarkan Usia Kerja Produktif

\begin{tabular}{|c|c|c|c|}
\hline Kategori & Kriteria & $\begin{array}{r}\text { Jumlah } \\
\text { (Jiwa) }\end{array}$ & Persentase \\
\hline Produktif & $46-65$ & 23 & 67,64 \\
\hline $\begin{array}{l}\text { Sangat } \\
\text { Produktif }\end{array}$ & $15-45$ & 11 & 32,36 \\
\hline $\begin{array}{l}\text { Kurang } \\
\text { Produktif }\end{array}$ & $\begin{array}{c}<15 \text { dan } \\
>65\end{array}$ & - & - \\
\hline \multicolumn{2}{|c|}{ Jumlah } & 34 & 100,00 \\
\hline
\end{tabular}

Sumber: Data Primer hasil wawancara

Masyarakat rumahtangga nelayan terubuk di Kabupaten Bengkalis didominasi oleh kelompok usia produktif, yaitu sebanyak 23 jiwa $(67,64 \%)$, sedangkan nelayan kelompok umur sangat produktif berjumlah 18 jiwa $(32,36 \%)$ kondisi ini idealnya dapat berpengaruh baik terhadap hasil usaha penangkapan ikan terubuk dikabupaten bengkalis tersebut, karena didominasi umur produktif menandakan adanya kemampuan yang 
begitu besar dalam perkembangan usaha penangkapan ikan terubuk khususnya dikabupaten bengkalis.

\section{Hasil Wawancara dengan Informan}

Bapak ms mangatakan memang kebanyakan yang menjadi nelayan terubuk ini adalah orang-orang yang dari kecil atau masih sekolah sd sudah membantu orang tua menangkap ikan terubuk di selat bengkalis, jadi bisa dikatakan kami menjadi nelayan terubuk ini sudah hampir 20 tahun lebih dan usia kamipun kebanyakan diatas 45 tahun keatas.

\section{Pendidikan}

Suatu hal yang perlu diperhatikan dalam menetukan kualitas sumberdaya manusia adalah pendidikan. Dari penelitian ini dapat diketahui jumlah informan rumah tangga nelayan terubuk yang berubah penghidupannya yang tidak tamat SD 19 jiwa, tamat SD 12 jiwa, tamat SMP 3 jiwa. Untuk mengetahui sebaran responden rumah tangga masyarakat nelayan terubuk yang berubah penghidupannya berdasarkan tingkat pendidikan di Kabupaten Bengkalis dapat dilihat pada Tabel 2.

Tabel 2. Sebaran Responden Rumah Tangga Masyarakat Nelayan berbasis perikananTerubuk Berdasarkan Tingkat Pendidikan

\begin{tabular}{|c|c|c|c|}
\hline $\begin{array}{c}\text { Lama } \\
\text { Pendididkan } \\
\end{array}$ & Kategori & $\begin{array}{r}\text { Jumlah } \\
\text { (Jiwa) } \\
\end{array}$ & Persentase \\
\hline $\begin{aligned} & 0-6 \\
\leq & 6 \text { Tahun }\end{aligned}$ & $\begin{array}{l}\text { Sangat } \\
\text { Rendah } \\
\text { Rendah }\end{array}$ & $\begin{array}{l}19 \\
12\end{array}$ & $\begin{array}{l}55,88 \\
35,29\end{array}$ \\
\hline $\begin{array}{c}7-12 \\
\text { Tahun } \\
>12 \text { Tahun }\end{array}$ & $\begin{array}{l}\text { Sedang } \\
\text { Tinggi }\end{array}$ & 3 & $\begin{array}{c}08,82 \\
- \\
\end{array}$ \\
\hline Juml & & 34 & 100,00 \\
\hline
\end{tabular}

Tabel 2. Memperlihatkan bahwa sebagian besar pendidikan responden rumah tangga masyarakat nelayan terubuk berada pada kategori sangat rendah sebanyak 19 jiwa $(55,88 \%)$, kategori rendah sebanyak 12 jiwa $(35,29 \%)$ dan kategori sedang sebanyak 3 jiwa $(08,82 \%)$. Dengan demikian dapat diambil kesimpulan bahwa tingkat pendidikan responden tergolong sangat rendah. Rendahnya tingkat pendidikan responden ini disebabkan oleh kemauan dan sarana prasarana yang menunjang kurang, serta kurangnya perhatian pemerintah.

\section{Jumlah Tanggungan Keluarga}

Jumlah tanggungan adalah banyaknya anggota keluarga yang menjadi tanggungan kepala keluarga yang terdiri dari istri, anak dan anggota keluarga lain termasuk kepala keluarga itu sendiri yang menjadi tanggungan keluarga tersebut. Jumlah tanggungan keluarga nelayan bebasis perikanan terubuk berkisar antara 2 sampai 5 orang. Jumlah tanggungan digolongkan kedalam empat kategori, yaitu kategori Sangat rendah rendah ( $<2$ orang), rendah (3- 4 orang), sedang (4-5orang), dan tinggi ( $>5$ orang). Untuk mengetahui sebaran responden berdasarkan jumlah tanggungan dapat dilahat padaTabel3.

Tabel 3. Sebaran Informan Berbasis Perikanan Terubuk Berdasarkan JumlahTanggungan

\begin{tabular}{|c|c|c|c|}
\hline Kategori & Kriteria & $\begin{array}{r}\text { Jumlah } \\
\text { (Jiwa) }\end{array}$ & Persentase \\
\hline Sangatrendah & $<2$ & 4 & 11,76 \\
\hline Rendah & $3-4$ & 9 & 26,47 \\
\hline Sedang & $4-5$ & 14 & 41,17 \\
\hline Tinggi & $>5$ & 7 & 20,58 \\
\hline \multicolumn{2}{|c|}{ Jumlah } & 34 & 100,00 \\
\hline
\end{tabular}

Sumber: Data Primer

Tabel 3 memperlihatkan bahwa jumlah tanggungan keluarga responden rumah tangga masyarakat nelayan terubuk sebagian besar berada pada kategori sangat rendah yaitu sebanyak 4 jiwa $(11,76 \%)$, kategori rendah 9 jiwa (26,47\%) sedang 14 jiwa (41,17\%), dan kategori tinggi 7 jiwa (20,58\%). Responden rumah tangga nelayan dengan jumlah tanggungan yang dikategorikan rendah adalah responden yang hanya memiliki tanggungan istri, anak, dan kepala keluarga itu sendiri, bahkan ada dalam satu keluarga hanya 
ada istri dan kepala keluarga itu sendiri. Responden pada kategori sedang dan kategori tinggi adalah responden yang memiliki tanggungan keluarga yang terdiri dari istri, anak, dan orang tua mereka.

\section{Pengalaman Kerja}

Pengalamaan kerja adalah ukuran tentang lama waktu atau masa kerja yang telah ditempuh seseorang dapat memahami tugas-tugas suatu pekerjaan dan telah melaksankan dengan baik (Ranupandojo,1989), pengalaman kerja adalah pengetahuan atau keterampilan yang telah diketahui dan dikuasai sesorang yang akibat dari perbuatan atau pekerjaan yang telah dilakukan selama beberapa waktu tertentu. Faktor pengalaman ini secara teoritis dalam buku, tidak ada yang membahas bahwa pengalaman merupakan fungsi dari pendapatan atau keuntungan. Namun, dalam aktivitas nelayan terubuk dengan semakin berpengalamannya, nelayan terubuk yang semakin berpengalaman dalam menangkap ikan bisa meningkatan pendapatan atau keuntungan Pengalaman bekerja responden nelayan terubuk di Kabupaten Bengkalis sebagian besar lebih dari 15 tahun, yakni sebanyak 11 jiwa (100\%). Untuk mengetahui sebaran nelayanDesa Seberang Taluk berdasarkan tingkat pengalaman berusahadapat dilihat pada Tabel 4.

Tabel 4. Sebaran Responden Nelayan Berbasis Perikanan Terubuk Berdasarkan Pengalaman Kerja

\begin{tabular}{|c|c|c|c|}
\hline Kategori & Kriteria & $\begin{array}{r}\text { Jumlah } \\
\text { (Jiwa) }\end{array}$ & Persentase \\
\hline Rendah & $\begin{array}{l}<10 \\
\text { Tahun }\end{array}$ & 4 & 11,76 \\
\hline Sedang & $\begin{array}{l}10-15 \\
\text { Tahun }\end{array}$ & 7 & 20,58 \\
\hline Tinggi & $\begin{array}{c}>15 \\
\text { Tahun } \\
\end{array}$ & 23 & 67,64 \\
\hline \multicolumn{2}{|c|}{ Jumlah } & 34 & 100,00 \\
\hline
\end{tabular}

Sumber: Data Primer
Tabel 4. Memperlihatkan bahwa pengalaman kerja responden Nelayan Terubuk berada pada kategori rendah 4 jiwa $(11,76 \%)$,kategori sedang sebanyak 7 jiwa $(20,58 \%)$, dan kategori tinggi 23 jiwa $(67,64 \%)$, Banyaknya respondan yang mempunyai pengalaman kerja pada kategori tinggi ini dikarenakan pekerjaan sebagai nelayan merupakan pekerjaaan turun temurun dari sejak mereka masih kanak-kanak sudah mendapat pengalaman mengikuti orang tua mereka nelayan.

\section{Pendapatan}

Faktor pendapatan memiliki peranan besar dalam persoalan gizi dan kebiasaan makan masyarakat setempat (Berg 1986 diacu oleh Puspa 2007) Tabel Box I.

Tabel Box 1. Hasil wawancara dengan informan

Informan K, Mangatakan walaupun
dalam satu tahun kami menangkap ikan
terubuk hanya 4 bulan saja, tetapi hasil yang
kami dapatkan lumayan besar. Bisa dirata-
ratakan dalam satu tahun nelayan
berpenghasilan 20-25 juta/nelayan, jadi
apabila dimusim-musim terubuk kami dilarang
menangkap terubuk rasanya rugi besar kami,
karena momen-momen musim terubuk ini
sangat ditunggu-tunggu oleh semua nelayan
terubuk, ibaratnya apabila ada anak kami
yang sakit tidak terlalu parah,hal itu kami
tinggalkan demi untuk menangkap terubuk,
karena dari hasil menangkap tersebut kami
bisa membawa anak kami berobat, Apalagi
harga telur ikan terubuk yang sudah kering
harganya bisa mencapai 2juta/kg

nelayan terubuk ini bersumber dari hasil tangkapan mereka setiap pergi mencari ikan dimana rumah tangga nelayan yang menjadi informan pada umumnya adalah kepala rumah tangga. Untuk memenuhi kebutuhan mereka, maka anggota keluarga nelayan biasanya ikut membantu bekerja. Berdasarkan keterangan yang diperoleh dari informan rumah tangga nelayan terubuk,pendapatan yang mereka peroleh hanya dapat memenuhi 
kebutuhan sehari-hari saja. Pada umumnya pendapatan mereka perbulan tidak menetap. Kenyataan ini dapat dipahami bahwa ketidakpastian mamperoleh ikan dan usaha penangkapan ikan cukup besar. Hal ini dipengaruhi oleh faktor musim, alat penangkapan yang mereka pergunakan serta armada yang digunakan.

\section{Eksternal}

Bertambahnya Jumlah Nelayan Ikan Terubuk

Dari hasil wawancara peneliti dengan informan dilapangan, bahwa hampir setiap tahun nelayan yang melakukan usaha penangkapan ikan terubuk di perairan selat bengkalis ini bertambah jumlahnya hal ini terlihat dari jumlah kapal yang beroperasi diperairan selat bengkalis semakin banyak pada saat musim ikan terubuk ini membuktikan bahwa menjadi nelayan terubuk merupakan salah satu alternafit masyarakat untuk memenuhi kebutuhan hidup, dan menjadi nelayan terubuk kehidupan masyarakat lebih sejahtera dan merupakan salah satu solusi untuk bertahan hidup karena dimasa sekarang untuk mencari pekerjaan sulit, apalagi kurangnya kemampuan masyarakat dibidang yang lain, begitu juga dengan pendidikan masyarakat rendah bahkan banyak yang tidak sekolah, mungking dengan menjadi nelayan terubuk masyarakat tidak harus memerlukan kemampuan khusus seperti sekolah dan syarat-syarat yang lain, maka dari itulah jumlah nelayan yang melakukan usaha penangkapan ikan terubuk di perairan selat bengkalis setiap tahunnya bertambah, karena menjadi nelayan terubuk mendapatkan hasil dan keuntungan yang cukup menjanjikan.

\section{Bertambahnya Jumlah Alat Tangkap Nelayan}

Dari hasil wawancara dengan informan nelayan terubuk menggunakan alat tangkap gillnet, Gillnet sering diterjemahkan dengan "jaring insang", "jaring rahang", dan lain sebagainya. Istilah "gill net" didasarkan pada pemikiran bahwa ikan-ikan yang tertangkap "gilled-terjerat" pada sekitar operculum nya pada mata jaring. Sedangkan "gill net dasar" atau "bottom gill net" adalah jaring insang, jaring rahang yang cara operasinya ataupun kedudukan jaring pada fishing ground direntangkan pada dasar laut, yang demikian berarti jenis-jenis ikan yang menjadi tujuan penangkapan ialah ikanikan dasar (bottom fish) ataupun ikanikan damersal, dengan bahan jaring terbuat dari multi fibre.Khusus untuk menangkap terubuk nelayan menggunakan alat tangkap gillnet dengan ukuran mesh 1-3 inci, tetapi untuk nelayan sei pakning 2-2,5 inci dan nelayan bengkalis seperti penampi dan sungai alam rata-rata meshnya 3 inci, dahulu 1 orang nelayan hanya memilki 1 pish jaring saja karena penangkapan ikan terubuk dilakukan di permukan perairan saja, tetapi untuk sekarang satu orang nelayan minimal mempunyai 10 pish jaring karena pengoperasi dan penangkapan ikan terubuk ini sudah jauh kedasar perairan yang mana jarak pelampung dari tinggi jaring 7-10 meter dan lebar jaring kurang lebih 10 meter jadi jarak dari permukaan kedasar jaring kira-kira 2030 meter, dengan bertambahnya jumlah jaring yang dimiliki nelayan tentu ini membuat peanmbahan biaya yang harus dikeluarkan oleh nelayan.

\section{Faktor Jarak Tempuh Melaut}

Dari hasil wawancara dilapangan dengan informan nelayannelayan yang melakukan usaha penangkapan ikan terubuk ini kebanyakan nelayan harian pergi pagi pulang sore, terutama nelayan yang berasal dari Desa Dompas dan Desa Sejanggat Karena fishing ground ikan terubuk berada didepan Desa Dompas dan Sejanggat (Sungai Pankning), tetapi untuk nelayan yang berasal dari Desa Penampi dan Sungai Alam (Pulau 
Bengkalis) Memerlukan waktu kira-kira 1-1,5 jam untuk sampai di perairan Selat Bengkalis (fishing Ground), dan dari dahulu sampai sekarang lokasi penangkapan ikan terubuk ini tidak berubah-ubah/tetap, dalam satu hari satu malam nelayan 3 kali lempar jaring 1 kali siang hari dan 2 kali pada malam hari, serta lamanya waktu pengoperasian alat tangkap ikan terubuk 3 jam.

\section{Overfishing}

Overfishing atau penangkapan berlebih merupakan kondisi dimana tingkat pemanfaatan sumberdaya ikan melebihi batasan yang ditetapkan sehingga dapat menyebabkan penurunan stok (deplesi) sumberdaya ikan. Apalagi penangkapan ikan terubuk dilakukan pada saat musim-musim terubuk beruaya keselat bengkalis, momen/ musim terubuk masuk ke perairan selat bengkalis ini adalah waktu yang ditunggu oleh semua nelayan terkhususnya nelayan terubuk, yang menjadi target utama adalah ikan terubuk betina dan sedang bertelur karena harga ikan terubuk betina ini mahal apalagi telurnya, bayangkankan apabila penangkapan dilakukan secara berlebih membuat jumlah terubuk berkurang apalagi ikan terubuk betina yang banyak tetangkap, sehingga membuat populasi terubuk ini berkurang setiap tahunnya. Hasil wawancara dengan salah satu informan dilapangan,
Tabel box 2. Hasil wawancara dengan informan

Ma (48 tahun), mengutarakan, sebenarnya yang membuat jumlah ikan terubuk ini berkurang bukan kami sebagai nelayan melakukan penangkapan yang berlebihan tetapi memang jumlah ikan terubuk ini saja yang memang tidak ada lagi karena air sungai bengkalis ini sudah tidak bagus lagi, belum lagi kapal-kapal yang membuang sisa minyak ke perairan bengkalis ini, kalau memang ikan terubuk ini sudah mau habis saya rasa sudah lama, tetapi sampai saat ini kami masih bisa menangkap ikan terubuk dan jumlahnya juga lumayan banyak,memang ukurannya saja yang agak lebih kecil dibandingkan tahun 1960 dulu. Ma juga menambahkan pengalaman dari dahulu sampai sekarang apabila ikan terubuk masuk dan keluar ke perairan selat berkalis ini ada tanda-tanda kurang lebih 1-1,5 jam hari hujan ditambah angin kencang bercampur petir.

\section{Pencemaran perairan}

Perairan selat bengkalis merupakan perairan umum yang letaknya strategis diantara dua negara indonesia dan malaysia dan dekat dengan perairan perdagangan didunia selat malaka, serta periaran ini juga dialiran periaran sungai siak. Yang mana di sepanjang pingir sungai siak ini cukup banyak terdapat perusahaan dan pabrik-pabrik yang hampir sebagian besar membuang limbah perusahaan ke perairan sungai siak sehingga menyebabkan periaran sungai siak mengalami kekeruhan serta tingkat kecerahannyapun berkurang dan sudah tercemar, dimana perairan sungai siak ini mengalir ke perairan selat bengkalis dan menyebabkan perairan selat bengkalis juga mengalami pencemaran. Dahulu Sungai siak airnya jernih dan tingkat kekeruhannya kecil, tetapi untuk saat ini perairan sungai siak memiliki tingkat kekeruhannya sangat tinggi, yang mana kekeruhan perairan ini membuat ikan terubuk susah untuk bernafas karena overculum dan insangnya diselimuti oleh partikelpartikel kecil sehingga menyebabkan ikan susah bernafas bahkan bisa menyebabkan ikan bisa mati. Selain tingginya tingkat kekeruhan,kecerahan 
perairan selat bengkalis juga mengalami penurunan dan perubahan yang sangat dratis, dimasa lalu perairan selat bengkalis jernih jauh dari pencemaran dan bersih sehingga bisa dimanfaatkan oleh masyarakat untuk mencuci, mandi, bahkan untuk minum., tetapi dimasa sekarang perairan selat bengkalis ini sudah jauh mengalami perubahan serta perairan ini sudah tercemar, pencemran ini bukan saja disebabkan oleh limbahlimbah dari perusahaan tetapi tumpahan minyak juga merupakan salah satu penyebab tercemarnya perairan ini begitu juga dengan sampah-sampah dan limbah rumah tangga yang banyak masuk ke perairan selat bengkalis ini, dan untuk sekarang masyarakat boleh dikatakan tidak ada lagi yang menggunakan dan memanfaatkan air selat bengkalis karena perairan selat bengkalis ini sudah mengalami pencemran yang berat.

\section{Transportasi Laut}

Perairan Bengkalis ini juga merupakan Open akses siapa saja boleh memanfaatkan baik itu dari nelayan setempat maupun nelayan dari tempat lain, selain itu perairan Bengkalis juga jga merupkan Fishing Ground ikan terubuk, yang mana di perairan Selat Bengkalis ini terdapat 16 stasiun penangkapan ikan terubuk, stasiun 8-11 merupkan zona inti pelestarian ikan terubuk. Hal ini dapat dimanfatkan oleh masyarakat untuk penangkapan ikan.

Informasi yang diperoleh : Selat Bengkalis merupakan zona pengangkapan ikan sehingga banyak nelayan-nelayan yang datang dari luar untuk melakukan penangkapan ikan, selain itu banyak juga terdapat kapalkapal yang datang dari luar baik kapalkapal perusahaan minyak Maupun Kapal yang membawa penumpang ketempat lain sebagai tempat lalu lintas, dan sering melewati area fishing ground ikan terubuk sehingga dapat merusak organisme dan alat tangkap nelayan, dan tidak dapat melakukan penangkapan. Selain itu juga dapat menyebabkan jaring-jaring nelayan terubuk yang ditabrak oleh kapal-kapal sehingga menbuat jaring nelayan rusak dan sobek dan membuat nelayan rugi, bahkan hampir dari sebagian nelayan banyak yang mengeluh dengan kejadian ini. Numun sejauh ini belum ada tindakan terhapap kapal-kapal yang beropersi diarena penangkapan nelayan, kami hanya bisa waspada dan berhatihati lagi dalam memilih lokasi operasi alat tangkap.

Dimensi Konteks Kerentanan

\begin{tabular}{|c|c|c|}
\hline \multirow[t]{2}{*}{ Dimensi } & \multicolumn{2}{|c|}{ Konteks Kerentanan } \\
\hline & Jangka Pendek & $\begin{array}{c}\text { Jangka } \\
\text { Panjang } \\
\text { dan Luas }\end{array}$ \\
\hline Natural & $\begin{array}{l}\text { - } \text { Berkurangnya Jumlah } \\
\text { Ikan Terubuk } \\
\text { - Ikan Terubuk Sulit } \\
\text { Dijumpai } \\
\text { - Ukuran Ikan Terubuk } \\
\text { Kecil-kecil } \\
\text { - Perairan Selat Bengkalis } \\
\text { Tercemar } \\
\text { - } \text { Berkurangnya Hasil } \\
\text { Tangkapan Nelayan } \\
\end{array}$ & $\begin{array}{l}\text { Kelestarian } \\
\text { Ikan } \\
\text { Terubuk } \\
\text { Terancam } \\
\text { Punah. }\end{array}$ \\
\hline Sosial & 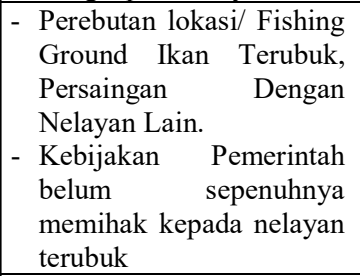 & $\begin{array}{l}\text { Terjadinya } \\
\text { Konfik }\end{array}$ \\
\hline Ekonomi & $\begin{array}{llc}\text { - } & \text { Fluktuasi Harga BBM } \\
\text { - } & \text { Fluktuasi Nilai Tukar } \\
& \text { Rupiah } & \\
\text { - } & \text { Fluktuasi } & \\
& \text { Komoditi } \quad \text { Perikanan } \\
& \text { Khusus Ikan Terubuk. } \\
\text { - } & \text { Pemasaran Ikan Terubuk } \\
\end{array}$ & $\begin{array}{l}\text { Krisis } \\
\text { Ekonomi }\end{array}$ \\
\hline Politik & 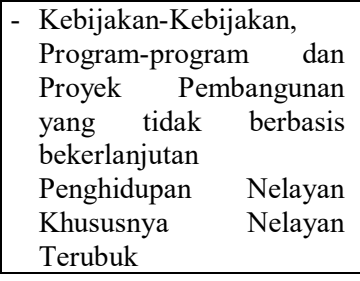 & $\begin{array}{l}\text { Krisis } \\
\text { Kepemimp } \\
\text { inan }\end{array}$ \\
\hline & mber-sumber & entanan \\
\hline $\begin{array}{l}\text { penghide } \\
\text { terubuk } \\
\text { cara-cara } \\
\text { sumberd } \\
\text { sungai r } \\
\text { penggun } \\
\text { nemerint }\end{array}$ & $\begin{array}{l}\text { pan masyarakat } \\
\text { dapat pula disebabk } \\
\text { dan taktik dalam pem } \\
\text { ya perairan dan e } \\
\text { laupun muara sungai } \\
\text { an alat yang dilara } \\
\text { h yang membuat }\end{array}$ & $\begin{array}{l}\text { nelayan } \\
\text { an oleh } \\
\text { anfaatan } \\
\text { osistem } \\
\text { seperti } \\
\text { ig oleh }\end{array}$ \\
\hline
\end{tabular}


kecil mati dan punah serta kurangnya tumbuhanair lainnya.Terkontaminasinya ikan terubuk ini memmbuat serta memicu terjadinya konflik antar nelayan. Perkembangan teknologi penangkapan ikan dapat pula menjadi konteks kerentanan jangka panjang bagi nelayan terubuk, yang mana selama ini nelayan terubuk menangkap ikan masih secara tradisional dan mengggunakan alat seadanya saja dan hampir semua peralat yang digunakan untuk menangkapan ikan terubuk masih menggunakan tenaga manusia.

\section{Kebijakan Pemerintah}

Upaya lain yang telah dilakukan oleh pemerintah untuk meningkatkan kualitas hidup nelayan diantaranya adalah melalui program penyaluran kredit usaha kepada nelayan dan bantuan subsidi bahan bakar minyak (BBM), Keputusan Menteri Pertanian No. 607.Kpts/Um/9/1976 tentang pembagian wilayah penangkapan berdasarkan tingkat kualifikasi peralatan tangkap yang dimiliki oleh nelayan, Keppres No.39/1980 tentang penghapusan operasi kapal pukat harimau, Undang-undang Nomor 27 Tahun 2007 tentang Pengelolaan Wilayah Pesisir dan Pulau-pulau Kecil serta lahirnya Keputusan Presiden Nomor 10 Tahun 2011 tentang Tim Koordinasi Peningkatan dan Perluasan Program Pro-Rakyat yang mengalokasikan dana sebesar Rp.927,82 miliar untuk menyejahterakan nelayan. Dalam kenyataannya, penegakkan regulasi dan implementasi program-program tersebut hingga saat ini sangat lemah. Ada indikasi seolah-olah regulasi dan kebijakan tersebut tidak pernah ada sebagaimana stagnasi yang terjadi pada peningkatan kesejahteraan hidup nelayan. Ujungnya, pengalokasian sumberdaya dan sumberdana dalam sistem perikanan perikanan tangkap bagi nelayan kecil masih jauh dari kondisi yang dapat meningkatkan kualitas hidup nelayan.

\section{Hasil Wawancara dengan Informan}

AK (45) Mengutarakan, Sebenarnya Peraturan pemerintah ini tidak terlalu mengikat dan memaksa nelayan. Peraturan pelarangan menangkap ikan terubuk ini hanya pada musim puncaknya saja seperti bulan 8-11 saja itupun hanya untuk penangkapan yang dilakukan pada siang hari saja dizona inti, tetapi penangkapan pada malam hari tidak ada pelarangnnya. Untuk Bulan-bulan lain diluar dari 4 bulan tersebut nelayan tidak dilarang untuk menangkap ikan terubuk, kami sebagai nelayan akan patuh terhadap peraturan pemerintah, tetapi kami berhadap hendaknya pemerintah juga lebih serius lagi untuk memperhatikan kami sebagai nelayan kecil dan memberikan solusi, dan hendaknya peraturan ini bukan saja berlalu untuk nelayan Bengkalis saja tetapi juga untuk nelayan Siak dan Meranti,apabila dimasa pelarangan nelayan meranti dan siak Menangkap kamipun juga ikut menangkap karena rugi besar kami.

Perubahan Penghidupan rumah tangga nelayan berbasis perikanan terubuk disebabkan terjadinya perubahan lingkungan baik itu dari asfek ekologikal maupaun dari asfek sosialkultur. Perubahan penghidupan nelayan berbasis perikanan terubuk ini terjadi dari tingkat individu maupun tingkat rumah tangga selain itu perubahan ini di pengaruhi oleh 2 faktor, baik faktor internal maupun faktor eksternal.

Berbagai upaya-upaya yang dilakukan oleh pemerintah untuk mengurangi perubahan dan kerentanan rumah tangga nelayan seperti dalam melestarikan ikan terubuk ini seperti sosialisasi peraturan-peraturan pemerintah, mebuat kawasan konservasi ikan terubuk yang berlokasi di Selat Bengkalis dan sekitarnya Berbagai upaya penyelamatan perlu terus dilakukan, Membuat penangkaran terubuk, dan memberikan bantuanbantuan khusus untuk nelayan terubuk. 
SARAN

Patroli pengawasan sangat dibutuhkan pada masa-masa larangan penangkapan ikan terubuk untuk memberikan efek jera terhadap nelayan yang masih melakukan kegiatan penangkapan ikan terubuk di daerah yang dilarang tersebut. kegiatan patroli ini sebaiknya dilakukan paling tidak 1 (satu) kali pada masa larangan di bulan setiap bulannya.

\section{DAFTAR ACUAN}

Ashley, Caroline dan Diana Carney. 1999. Sustainable Livelihoods: Lessons from Early Experience. www.dfid.org.uk

Baiquni, M. 2007. Strategi Penghidupan di Masa Krisis.Idial Media, Yogyakarta.

Bekele, Adugna. E, 2008. Livelihood Strategies And Food Security Inwolayta, Southern Ethiopia: The Case of Bolososore District, Thesis Submitted to the Department of Rural Development and Agricultural Extension, Schoolof Graduate Studies Haramaya University

Carloni dan Crowley, 2005. Rapid Guide for Missions Analysing Local Institutions and Livelihoods

Chambers, R., 2006. Vulnerability, Coping and Policy (Editorial
Introduction).IDS Bulletin Volume 37 Number 4, September 2006. Institute of Development Studies. Diakses tanggal 27 Februari 2012

Carney, D. (1998).Implementing the Sustainable Rural Livelihoods Approach.In Carney (ed.) Sustainable Rural Livelihoods. What Contributions can we make? Department for International Development Nottingham: Russell Press Limited.

Livelihoods. Whosw 1995. Poverty and
Counts? Dalam Environment
and Urbanization, Vol. 7 No. 1
April 1995.

Chambers, R. and Conway, G. 1992. Sustainable Rural Livelihoods: Practical Concepts for the 21 Century. IDS Discussion Paper 296. Brighton: Institute of Development Studies

Chambers, Robert. 1987. Pembangunan Desa, Mulai dari Belakang. Jakarta: LP3ES

\section{Email :}

afrizals2.unri@gmail.com naini61gope@gmail.com rifo.amvik@gmail.com 